\title{
TAF5 Gene
}

National Cancer Institute

\section{Source}

National Cancer Institute. TAF5 Gene. NCI Thesaurus. Code C20505.

This gene plays a role in transcriptional initiation and core promoter-specific function. 